\title{
Tax sparing clauses as a policy instrument of developing countries: evidence from the Latin- American tax treaty network
}

\author{
Aitor Navarro ${ }^{1}$ \\ Carlos III University, Madrid, Spain
}

\begin{abstract}
Developing countries frequently grant corporate income tax incentives in order to attract foreign direct investment. To secure the effectiveness of these measures at a cross-border level, tax sparing clauses secure a notional credit at residence, meaning a discount on the taxes due even if no or lower taxes were paid at source. These clauses prevent the home country of the investor from taxing that income, allowing the investor to retain the tax spared by the host country. This contribution examines the rationale of tax sparing and conducts an examination of the issue from the perspective of the Latin-American tax treaty network - comprising more than 250 treaties - to draw relevant conclusions from the analysis of the specific clauses included in these agreements.
\end{abstract}

Keywords: Tax treaties, developing countries, tax sparing, LatinAmerica, GloBE.

\section{Introduction}

Developing countries frequently grant corporate income tax incentives in order to attract foreign direct investment that ultimately contributes to economic growth. The impact of these measures depends very much on their proper design, implementation, and effectiveness. Notwithstanding, in specific scenarios, the adoption of these incentives to execute specific policies becomes nullified at a cross-border level when the home country of a foreign direct investor adopts a capital export neutrality policy by eliminating double taxation through the credit method. As the credit is based on taxes that are effectively paid abroad, the amount of taxes saved

\footnotetext{
${ }^{1}$ Email: aitor.navarro@uc3m.es
} 
due to the host country's incentives will not reduce the amount of taxes levied in the home country, meaning that the said tax incentives are offset. This entails a transfer of resources from the host country granting a tax incentive -usually a developing country-to the home country of the investor -often a developed country- instead of allowing the investor to retain the tax spared by the former (Holland and Vann 1998, 25; Schoueri 2006, 216; Li 2007, 707; Xu 2017, 132; Ferreira and Perdelwitz 2018, 6.3.1). The country of residence would collect the tax foregone by the source state through reductions posed in the tax treaty or domestically thereby hindering the effectiveness of tax incentives to attract foreign direct investment. The tax sparing mechanism resolves the issue by granting a notional credit at residence -specifically, a discount on the taxes due even if no or lower taxes were paid at source-therefore preserving the effectiveness of tax incentives by securing that the investor retains the tax that is waived. In terms of the $\operatorname{OECD}(1998,11)$, "tax sparing provisions basically enable the investor to obtain a foreign tax credit for the taxes that have been 'spared' (i.e., not paid) under the incentive regime of the source country or to ensure that these taxes will be taken into account to apply certain conditions that may be attached to exemption systems" (see also Brown, 2002, 78; Rust 2015, 1637; OECD 2017, 403). The following example, depicted in Nilsen $(2013,70)$, portrays the effects of a tax sparing clause:

\begin{tabular}{|l|c|c|c|}
\hline & $\begin{array}{l}\text { With tax } \\
\text { sparing }\end{array}$ & $\begin{array}{l}\text { Without tax } \\
\text { sparing }\end{array}$ & $\begin{array}{l}\text { Without tax } \\
\text { holiday }\end{array}$ \\
\hline The host State & & & \\
\hline Company business profits & 100 & 100 & 100 \\
Normal corporate income tax 25\% & 25 & 25 & 25 \\
Tax holiday 0\% & -25 & -25 & - \\
After tax profits & 100 & 100 & 75 \\
Dividends paid & 100 & 100 & 75 \\
Dividend withholding tax 15\% & 15 & 15 & 11,25 \\
After tax dividends & 85 & 85 & 63,75 \\
\hline The home State & & & \\
\hline Tax on recieved dividends 25\% & 10 & 10 & 7,5 \\
Received dividends & 75 & 75 & 56,75 \\
Indirect credit for notional tax & 25 & 0 & - \\
\hline Total tax liability & 0 & 25 & 18,75 \\
\hline After tax profit & $\mathbf{1 0 0}$ & $\mathbf{7 5}$ & $\mathbf{5 6 , 7 5}$ \\
\hline
\end{tabular}

Tax sparing is one of the most controversial topics in the field of tax treaties. It is linked to tax incentives and thus to no or lower taxation (Shannon 1992; Hines Jr. 2000; Laurey 2000; Brooks 2009; Brauner, 2013; Li 2018); it refers 
mainly to policy concerns of developing countries (UN 2017, 471); the United States has taken a strong position against these clauses -as this is the main reason of its underdeveloped tax treaty network with other countries in the American continent (Martin 1998, 445); and the OECD changed its view from positively endorsing these clauses to a significant reluctance in a 1998 report that remarks on their deficiencies (Kofler and Pötgens 2020, sec. 3.3.4). Moreover, the last chapter of this conundrum could mean the collapse of existing tax sparing clauses due to the increasing adoption of CFC rules plus an income inclusion rule as proposed by the OECD in its GloBE proposal in the name of the fight against double non-taxation.

Existing literature on tax sparing is divided between those that, from a tax policy perspective, support the use of tax sparing clauses versus those that highlight their inadequacies from the positions of developed and developing countries. Not so often, the focus is on the adoption of these clauses in the tax treaty network of a particular region or the examination of specific clauses adopted in double tax treaties (Ashiabor 1998; Oguttu 2011; Silva 2013; Hu and Na 2018; Andrade 2020) even though these are nonmodeled clauses that pose relevant design and interpretation issues that deserve further attention. This contribution attempts to address this topic in what concerns the policy rationale of tax sparing clauses and its reflection in the tax treaty network of Latin-America ${ }^{2}$. The purpose is to conduct a comprehensive classification and examination of all of its provisions that are currently in force.

The Latin-American region is of great interest when approaching the topic of tax sparing due to its remarkable diversity comprising three OECD countries (Chile, Mexico, and Colombia); a country that forms part of the BRICS (Brazil); an investment hub (Panama); and a wide variety of levels of economic development. The Latin-American tax treaty network includes 252 double taxation conventions in force pertaining to 16 countries.

\footnotetext{
${ }^{2}$ The exact scope of the expression "Latin-America" remains controversial. In this contribution, it is meant to designate all American countries in which Spanish is the spoken language of the majority plus Brazil. An alternative, more accurate denomination would be "Ibero-America" referring to former colonies of the countries comprising the Iberian Peninsula, namely Spain and Portugal. The reason to instead choose "Latin-America" lies on the fact that, for an English-speaking public, this is a much more recognizable expression.
} 


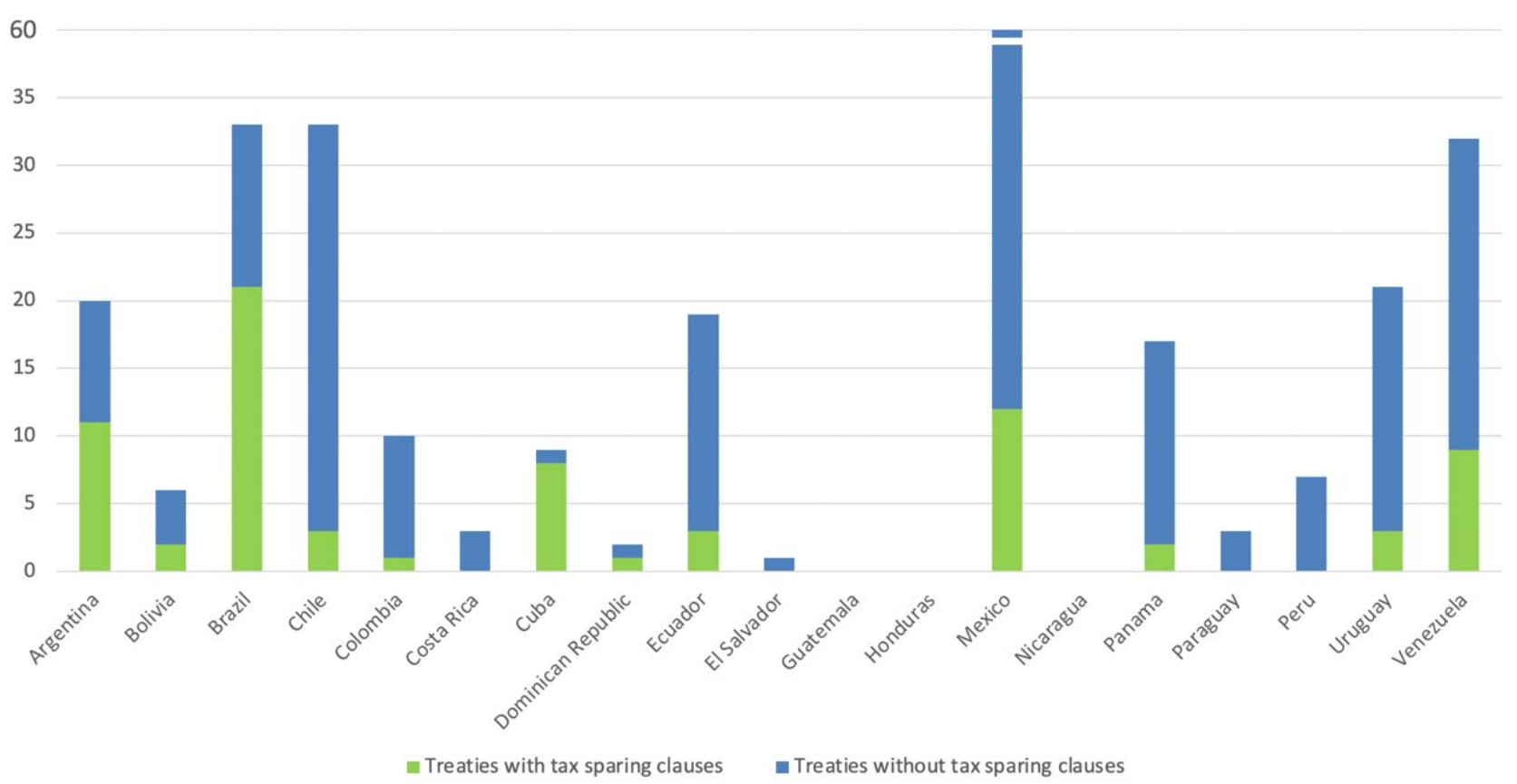

The exact number of bilateral tax treaties in force per country is as follows: Argentina (20), Bolivia (6), Brazil (33), Chile (33), Colombia (10), Costa Rica (3), Cuba (9), Dominican Republic (2), Ecuador (19), El Salvador (1), Mexico (60), Panama (17), Paraguay (3), Peru (7), Uruguay (21), and Venezuela (32). Among these treaties, only 24 are signed between countries in the region ${ }^{3}$ alongside Decision 578 of the Andean Community, a multilateral agreement on the avoidance of double taxation that is applicable in Bolivia, Colombia, Ecuador, and Peru. These agreements are publicly available on the internet, usually on the official webpages of the referred countries' public revenue services. Notwithstanding, the author retrieved them from the IBFD database for their examination ${ }^{4}$ as it is a centralized source and contains an English translation of all of the said treaties. The entire Latin-American tax

\footnotetext{
${ }^{3}$ Here is the list without reiterations: Treaties of Argentina (with Bolivia, Brazil, Chile, and Mexico), Brazil (with Chile, Ecuador, Mexico, Peru, and Venezuela), Chile (with Colombia, Ecuador, Mexico, Paraguay, Peru, and Uruguay), Colombia (with Mexico), Costa Rica (with Mexico), Cuba (with Venezuela), Ecuador (with Mexico and Uruguay), Mexico (with Panama, Peru, and Uruguay), and Paraguay (with Uruguay).

${ }^{4}$ See https://www.ibfd.org/IBFD-Tax-Portal/Tax-Research-Platform (subscription service, last accessed on June 27th, 2020).
} 
treaty network was examined in order to determine the exact number and content of tax sparing clauses, build a proper taxonomy, and derive relevant findings. In this regard, 73 tax sparing clauses were found and classified accordingly. It will be shown that the diversity of the region turns into a substantial disparity in the policy choices regarding tax sparing as it varies significantly from country to country.

As per the structure of the paper, section 2 refers to the rationale of tax sparing clauses. Arguments in favor and against the adoption of tax sparing clauses will be addressed from the perspectives of developed and developing countries. Section 3 is devoted to examining the tax sparing clauses that are present in the Latin-American tax treaty network. Specific clauses will be further analyzed and resulting remarks will be drawn. Section 4 concludes.

\section{The rationale of tax sparing clauses}

The first idea that must be borne in mind to adequately approach the subject matter is that tax sparing clauses comprise two categories: contingent tax sparing and matching credit clauses. Although the classification of tax sparing clauses has not always been well-defined (Ferreira and Marinho 2013), a review of the said clauses' scope and effects reveals that their range and impact are fairly different hence the relevance of the distinction. On the one hand, contingent tax sparing clauses require the residence state to grant a notional credit equivalent to the tax foregone by the source state due to applying a tax incentive scheme compared to the normal taxation level as if the incentive did not exist. Eligible incentive schemes are sometimes explicitly identified in the clause (Nilsen 2013, 12). In contrast, others contain a generic reference as will be shown below in section 3.1 with the case of the clauses present in the Latin-American region.

On the other hand, matching credit clauses ensure a minimum level of credit to be granted in the state of residence irrespective of the state of source's specific taxation level or the giving of tax incentives therein (Sas and Diplotti 2005, 697; Schoueri 2013, 111). The main difference with the contingent variant of tax sparing lies in predetermining the exact amount of credit granted at residence that is not dependent on the specific application of any tax incentive at source. Hence, when the source state decides to reduce the tax burden of an item of income through a matching credit clause, the taxpayer will benefit from such a reduction and not the state of 
residence. This outcome would take place regardless of whether this reduction may be labeled as a tax incentive. The spread between the percentage that is granted as a notional credit and the tax rate that is imposed by the state represents the tax benefit gained by the taxpayer. Additionally, it must be emphasized that a matching credit clause's functioning is more straightforward than that of a contingent tax sparing clause (Rust 2015, 1639) because it is not needed to ascertain the compliance with the requirements envisaged in any domestic tax incentive measure.

Tax sparing clauses are a relevant expression of the fiscal sovereignty of those states that demand the adoption of the clause in their double tax treaty network. According to Schoueri $(2013,121)$, when a country agrees to limit its taxing rights, it implies recognizing the jurisdiction to tax of the counterpart. Yet, the opposite, i.e. the ascertainment of the jurisdiction to not tax an item of income, remains controversial in the context of the credit method. When the source jurisdiction decides not to tax a specific item of income, the residence jurisdiction will be afforded the opportunity to tax it as no credit will be granted and therefore no reduction of taxes will take place. Stated differently, the jurisdiction of the source state not to tax an item of income is annulled by the residence state in the event that the credit method is adopted and no tax sparing provision is agreed.

Often, the implementation of tax sparing is considered by developing countries as a quid pro quo to lower withholding tax rates that entail double tax treaties (Martin 1998, 454; Dagan 2000; 994). Without such a clause, lower rates at source would not necessarily promote investment as the home country would tax the income that remains untaxed by the source state due to the functioning of the credit method, the calculation of which is based on taxes paid abroad. The advantage would only be from a cash flow perspective as withholding taxes apply when the payment occurs while residence-based taxation is usually levied once per year. Hence, if the rationale behind lowering source taxation is to promote investment, there is a possible threat that the effectiveness of this policy reason will be annulled by the residence state in the described terms. This is the primary reason why tax sparing is a critical element for countries willing to attract investors at the expense of tax revenues. 
With that in mind, perhaps the most compelling argument raised against tax sparing consists of denying the premise that builds its reason for existence, particularly that tax sparing clauses are not effective in promoting foreign investment. The 2017 OECD Commentaries to the Model Tax Convention (OECD 2017, 403) still sustain that one of the main concerns of the overall usefulness of these clauses is "the effectiveness of tax sparing as an instrument of foreign aid to promote the economic development of the source country" even though neither the commentaries nor its 1998 report on the subject matter (OECD 1998) provide specific studies to uphold such inadequacies. Indeed, studies are pointing in the opposite direction, namely, the positive effect of tax sparing in foreign direct investment that increased home country foreign direct investment in the developing countries with which a tax treaty that included such a clause was signed. For instance, Hines Jr. (2000, 54-57) found that Japanese FDI is approximately 1.4 to 2.4 times greater in countries that have a tax sparing clause included in the relevant tax treaty. Furthermore, it was determined that Japanese investors benefited from reductions of $23 \%$ on the tax rate visà-vis United States investors. These results were then confirmed by Azémar, Desbordes, and Mucchielli (2007) who ascertained that Japanese FDI flows in tax sparing countries were almost three times higher compared to nontax sparing countries and that tax sparing provisions are taken into account in investors' strategic location choice decisions. Moreover, Azémar and Dharmapala (2019) ran a panel data on bilateral FDI stocks from 23 OECD countries in 113 developing and transition economies over the period 20022012, coding tax sparing provisions in all bilateral tax treaties among these countries. They found that tax sparing agreements are associated with up to $97 \%$ higher FDI. The said findings have also echoed in the tax literature on the subject (McDaniel 2003; Hu and Li 2015; Li 2017).

Another alleged disadvantage of the tax sparing clauses as seen from the perspective of the source state refers to the fact that they would promote the repatriation of profits from the source state and would thus encourage short term investment projects (OECD 1998, 42; Brooks 2009, 555; Santos $2015,18)$. However, this factor could be considered from a positive context when considering the potential advantageous effect on investment that entails the tax neutrality resulting from the said outcome (Haynes 1972, 769). Moreover, not including a tax sparing clause in the relevant treaty 
would not guarantee the reinvestment of income in the source state as reinvestment could occur anywhere else to enjoy deferral due to the lack of repatriation (Liebman 1978, 306). Reinvestment should be an aspect dealt with when designing the domestic tax incentive. This is not a concern of the implementation or layout of the tax sparing clause but instead a matter relevant to the state that is willing to implement the incentive.

The advantages and disadvantages of tax sparing clauses should not only be predicated from the source country but also from the residence state. The fact that tax sparing is granted to the residents of a specific jurisdiction implies a competitive advantage on costs -taxes spared- vis-à-vis other foreign investors operating in the same country that are tax residents in a jurisdiction not granting tax sparing (Darcy 1987, 397; Byrne 1998; Laurey 2000, 469; Toaze 2001, 885; McDaniel 2003, 291; Brooks 2009, 548). When comparing the effect of the incentives in domestic businesses with those of foreign investors not benefiting from a tax sparing clause, the latter remains in a disadvantageous position ( $\mathrm{Li} 2017,550$ ). However, tax sparing is contrary to capital export neutrality for which the rationale consists of granting neutrality to domestic and foreign investments from the perspective of the home country (Nilsen 2013, 15). The investment in a country with a tax treaty containing a tax sparing clause would entail a lower tax burden vis-à-vis a comparable domestic investment. This is the main reason why the United States has been reluctant to adopt these clauses in their tax treaty network (Surrey 1958, 1965; Liebman 1978, 307; Whittaker 1982, 59; Reese 1987, 380; Tillinghast 1995, 476; Laurey 2000, 486; Barker 2007, 362). Other relevant reasons that would justify the rejection of tax sparing by the United States that are noted by the literature include: 1) the impact of windfalls on those corporations that already invested in the developing country without requiring tax sparing to operate there is a relevant effect that should be taken into account (Surrey 1958, 159) and 2) the identification of the deem credits tax sparing clauses generate with expenditures on foreign aid which should be subject to closer scrutiny by the legislative body (Oh 1987, 51; Peroni 2003, 298).

That said, it must be stated that the very functioning of tax incentives and, accordingly, tax sparing, is to introduce distortions to favor foreign direct investment in the country granting these measures (Margalioth 2003, 181; McDaniel 2003, 287; Martínez Laguna 2017, 196). Hence, the residence 
country would have to adopt a policy decision to either grant neutrality or support the obtention of incentives by its resident enterprises investing abroad. On the other hand, the acceptance of the clause could be used as a bargaining chip by developed countries to obtain lower withholding tax limitations at source hence further reducing revenues obtained by developing countries (Martin 1998, 455; Toaze 2001; Long 2018, sec.2.7.1). Curiously enough, this argument is mentioned as a deficiency by the OECD $(1998,11)$ even though, as Schoueri highlights $(2013,115)$, the OECD Model Convention precisely favors the restriction of source taxation vis-à-vis the UN Model, for instance. Moreover, such an advantage is far from being clear. For instance, the United States' unwillingness to adopt tax sparing clauses is being used by the negotiators of developing countries to secure positions that are more favorable on other topics of their concern (Ashiabor 1998, 75).

By granting tax sparing, the residence country also assigns public resources to encourage investment (Liebman 1978, 303; Li 2018, sec.3.2). This is why, traditionally, the consideration of tax sparing as a foreign aid device to less developed countries have been such an essential topic in the discussion on the appropriateness of adopting these clauses in tax treaties (Barker 2007, 362). In fact, the first debates on the adoption of tax sparing clauses took place within the British Royal Commission on the Taxation of Profits and Income in 1953 -and again in 1956- to determine whether this measure should be offered to developing counterparties (Toaze, 883; Li 2017, 547). Mainly, the concern was whether a developed country such as the United Kingdom had to be considered itself bound to respect the tax incentives granted made by its lower-income colonies. Two arguments were considered in this regard: 1) Britain's responsibility for the economic development of its colonies and 2) the possible damage to Britain's external relations had they not addressed the issue seriously (Brooks 2009, 516). To define tax sparing as a foreign aid tool appears to be somehow paternalistic by itself (Reese 1987, 379; Tillinghast 1995, 476; Laurey 2000, 485). Yet, it could also be argued that, due to tax sparing, lower income countries can exercise their tax sovereignty and grant incentives without the control and accountability that often accompany direct aid offered by developed countries (Brooks 2009, 549). Tax sparing would prevent paternalism in 
that regard although perhaps at the expense of effectiveness (Martin 1998, 453).

Another challenging point to be mentioned regards the claims that tax sparing clauses could also be taken advantage of in an abusive manner through aggressive transfer pricing, round-tripping transactions, or treaty shopping (OECD 1998, 28). However, the abuse concerns the underlying tax incentives rather than the tax sparing clauses as such and, as Schoueri $(2013,117)$ convincingly affirmed, "if one were to consider not including a provision in a treaty because it would be subject to abuse, sooner or later no single article of tax treaties would survive". Moreover, the referred concerns may be addressed through anti-abuse devices at domestic and tax treaty levels, especially after the significant further development of these rules due to the BEPS Project (OECD 2015a, 2015b, 2015c).

Notwithstanding, the truth is that the policy rationale of tax sparing lies on promoting double non-taxation outcomes to foster foreign direct investment (Rust 2015, 1638) while the BEPS Project revolved around the adoption of measures preventing such an outcome. The focus has primarily been on scenarios in which it derived from "practices that artificially segregate taxable income from the activities that generate it" (OECD 2013, $13)$ or, as stated by Martínez Laguna $(2017,199)$, unintended double nontaxation. Indeed, in the scope of BEPS, the aim was -in principle- not to affect "intended" double non-taxation that agreed in tax treaties which is precisely what tax sparing clauses aim to achieve.

That said, the truth is that even the simplest form of tax sparing clauses, specifically those of matching credit, have been at the center of the discussion in court cases (see section 3.2). When a CFC rule applies and attributes income to the resident controlling person, no juridical double taxation arises and thus the relief method for double taxation that is present in tax treaties that would contain a tax sparing clause would not be applicable hence leaving the clause without effect. A New Zealand case on which Arnold (2018), Holmes (2018), and Elliffe (2019) commented may illustrate such a fear. A resident individual owned a 30\% participation in two Bermudan companies that owned interests in five Chinese resident companies that were considered controlled foreign companies under New Zealand CFC legislation. These companies benefited from Chinese tax incentives that would qualify the companies for a deemed credit under the 
tax sparing clause agreed in the tax treaty signed between New Zealand and China. This clause is contingent, and includes the list of the specific incentives that would trigger the recognition of a deemed credit.

The taxpayer was allowed a tax credit for the Chinese tax paid by the Chinese companies on the income attributed to her but was denied the deemed tax credit resulting from the tax sparing clause. The High Court decided in favor of applying the clause ${ }^{5}$, however, the Court of Appeal reversed the decision ${ }^{6}$. Mainly, the discussion was focused on whether Art.23.2.a) the tax credit rule that is applicable by New Zealand residents applies to economic double taxation; it was answered in the negative by the appeal decision. As noted by Arnold, actually, the main issue at stake should have referred to the applicability of CFC rules in a tax treaty setting in the first place, which was surprisingly not raised by the taxpayer (Arnold 2018, 436). Be that as it may, the truth is that the doctrine has long discussed such a problem, and there are several court decisions in favor and against the applicability of CFC rules in tax treaty scenarios as is shown by a compilation of references that may be found in Kuźniacki $(2015,760)$ and Hattingh $(2020,189)$. It is not the aim of this contribution to delve deeper into this discussion, however, it must be noted that CFC rules pose a significant danger to the effectiveness of tax sparing clauses. The double non-taxation outcome of tax sparing becomes nullified when the income is being effectively taxed in the residence state of the controlling entity or individual.

Beyond the threat of CFC rules, a significant turn in the course of action of the BEPS Project outcomes has occurred with the -still under consideration- OECD Global Anti-Base Erosion Proposal (GloBE) -also known as Pillar 2- of the intended Consensus Solution to the Tax Challenges Arising from the Digitalisation of the Economy (OECD 2019a, 2020; Blum 2019; Englisch and Becker 2019; Larking 2020). This proposal includes an income inclusion rule that would top up the taxation of cross-border income up to a minimum level expressed as a percentage. Specifically, "the income inclusion rule would operate as a minimum tax by requiring a shareholder

\footnotetext{
${ }^{5} \mathrm{NZ:}$ Lin v. Commissioner of Inland Revenue [2017] NZHC 969.

${ }^{6}$ NZ: Lin v. Commissioner of Inland Revenue [2018] NZCA 38. The decision was confirmed by the Supreme Court in Lin v. Commissioner of Inland Revenue [2018] NZSC 54, although no new arguments regarding the tax sparing clause were considered.
} 
in a corporation to bring into account a proportionate share of the income of that corporation if that income was not subject to an effective rate of tax above a minimum rate" (OECD 2019b, 7). If this measure is widely adopted at a domestic level, massive treaty dodging will take place, potentially leaving tax sparing clauses without any effect due to taxation at residence of income that was not intended to be taxed.

\section{Tax sparing clauses in the Latin-American tax treaty network}

As stated in the introduction, the Latin-American tax treaty network comprises 252 conventions in force pertaining to 16 countries out of which a total of 73 tax sparing clauses were found. Notwithstanding, 23 of these clauses contain a sunset provision that caused their current inapplicability ${ }^{7}$, i.e. almost one-third of the total number. Hence, 50 clauses are still enforceable and will be subject to analysis ${ }^{8}$.

Latin-American tax treaty network

(only countries with at least one tax sparing clause)

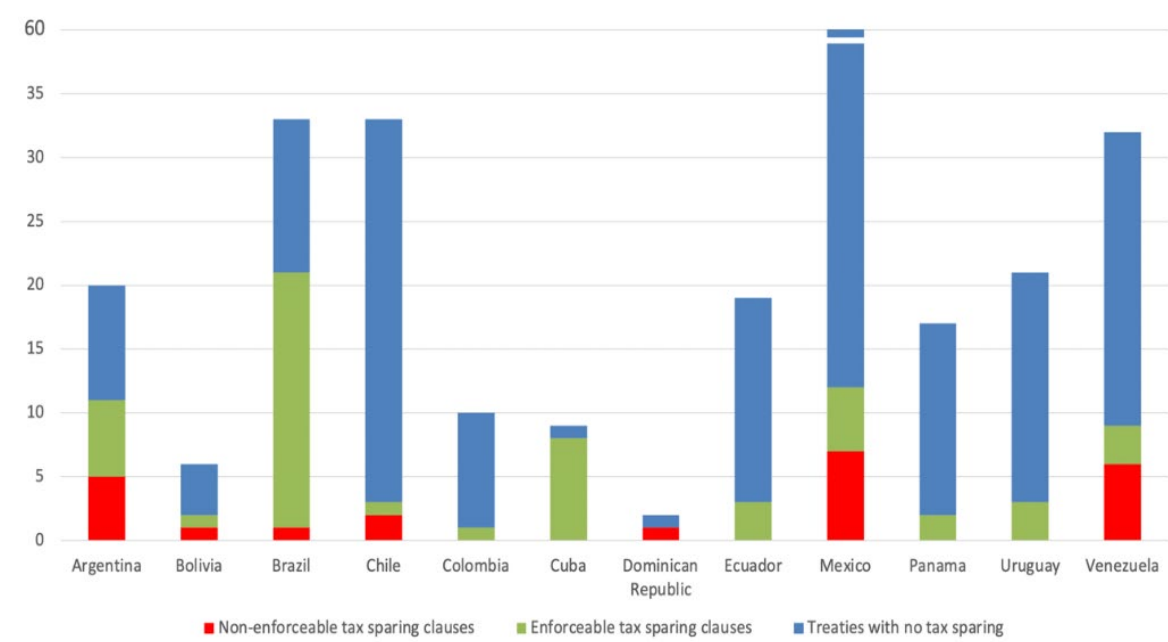

\footnotetext{
${ }^{7}$ Tax treaties of Argentina (with Denmark, France, Norway, Sweden and the United Kingdom), Bolivia (with Sweden), Brazil (with Belgium), Chile (with Malaysia and Thailand), Dominican Republic (Canada), Mexico (with Denmark, Finland, Japan, Netherlands, Norway, Sweden and the United Kingdom) and Venezuela (France, Germany, Netherlands, Norway, Sweden and the United Kingdom).

${ }^{8}$ Tax treaties of Argentina (with Australia, Canada, Finland, Germany, Italy, Spain), Bolivia (with Germany), Brazil (with Austria, Canada, Czech Republic, Denmark, Ecuador, Finland, France, Hungary, India, Italy, Japan including both a contingent tax sparing clause and a matching credit one-, Korea (Rep.), Luxembourg, Netherlands, Norway, Philippines, Slovak Republic, Spain and Sweden), Cuba (with Austria, China, Portugal, Qatar, Russia, Spain, Venezuela, Vietnam), Ecuador (Brazil, Germany, Uruguay), Mexico (France, Italy, Korea (Rep.), Singapore -including both a contingent tax sparing clause and a matching credit one-) Panama (Barbados, Vietnam), Uruguay (Ecuador, Germany, Vietnam), Venezuela (Barbados, Cuba, Malaysia).
} 
The jurisdiction that signed most clauses is Brazil, comprising 21 in a total of 33 tax treaties. The country with the highest ratio of clauses included per signed tax treaty is Cuba with 8 clauses out of 9 signed tax treaties. Argentina also shows a significant number of clauses with 11 out of 20 tax treaties, although five are non-applicable due to sunset provisions. Mexico also counts 12 tax sparing clauses -within a network of 60 tax treaties, the most numerous one within the region. However, all of them were included in tax treaties that entered into force from 1991 to 1997 -right before the publication of the OECD Report advocating for a reconsideration of the adoption of tax sparing clauses - and up to seven are not enforceable due to sunset provisions. Other countries demonstrate reluctance in the adoption of tax sparing. Panama, for instance, only counts two clauses in a network comprised of 17 treaties. The ratio is even lower in Colombia, which accessed the OECD in April 2020, with a network of ten tax treaties in force that only include one tax sparing clause present in the treaty signed with Switzerland. Chile, also an OECD Member State, has a network of 33 tax treaties in force in which only three tax sparing clauses were included due to the policy of the counterparties, i.e. Malaysia, Thailand, and Switzerland, although- most probably due to the sunset provisions included by Chileonly the Swiss clause remains in force.

The examination of the Latin-American tax treaty network's specific clauses will assume the distinction between contingent tax sparing clauses and matching credit clauses explained in the previous section as the scope and effects of each group of clauses vary significantly. Building a taxonomy helps to address interpretation issues more adequately and allows a better understanding of how to apply these rules and critically approach the court decisions that have dealt with these matters.

\section{Contingent tax sparing clauses}

Contingent tax sparing clauses grant tax sparing as long as the source state has reduced its taxation level due to exemptions or deductions of any kind. The tax that is spared will be equivalent to the tax that is applied at source had the referred incentives not applied. Only 18 clauses of these types are in force within the entire Latin-American tax treaty network ${ }^{9}$, meaning that

\footnotetext{
${ }^{9}$ Tax treaties of Argentina (with Australia and Canada), Brazil (with Japan), Cuba (with Austria, China, Portugal, Qatar, Russia, Spain, Venezuela and Vietnam), Ecuador (with Uruguay), Mexico (with Singapore), Panama (with
} 
the significance of such a tax policy instrument is residual compared with the total number of tax treaties in force. By examining their scope, two subcategories were found, specifically: i) contingent open clauses and ii) restrained contingent clauses.

i) The first category of contingent tax sparing clauses that were identified configures itself as an open clause, meaning that the types of relief applied in the state of source that qualifies to spare taxes at residence are broadly defined $^{10}$. For instance, Article 24.3 of the tax treaty signed between Cuba and Russia states:

Where a resident of a Contracting State derives income or owns elements of capital which, under the provisions of this Convention, may be taxed in the other Contracting State, the first State shall allow, as a deduction from the tax liability -as a tax credit- the amount that should have been theoretically paid in the other State in respect of a similar tax, but which was not paid because of an exemption, reduction, deduction or other forms of relief granted in the first-mentioned Contracting State.

This is perhaps the simplest form of a contingent tax sparing clause as it does not even require the applicability of a specific tax incentive or that the reduction of taxes is granted due to reasons linked to the country's economic development or the promotion of investment therein. Hence, exemptions, reductions, or deductions that are not strictly constrained to tax incentives could impact the specific amount of the "similar tax" to which the clause refers, i.e. the calculation of the notional credit to be granted at residence.

It has to be highlighted that these contingent open clauses afford ample opportunity for the country of source to adopt further modifications or new inclusions to its tax incentives schema as all tax savings obtained by the taxpayer will be eligible for being credited. The OECD noted that this configuration incentivizes source countries to artificially maintain high tax rates primarily to secure tax sparing benefits that are more significant (OECD 1998, 29). Notwithstanding, this reproach can only be predicated of

Barbados and Vietnam), Uruguay (with Ecuador and Vietnam) and Venezuela (with Barbados, Cuba and Malaysia).

${ }^{10}$ See the tax treaties of Cuba (with Portugal, Qatar, Russia and Venezuela). 
contingent tax sparing clauses as they refer to the calculation of the deemed credit to the taxes that would have usually been paid had a tax incentive specified in the clause or not- not been applied. On the other side, the predetermination of matching credit clauses completely avoids such an issue as, irrespective of the tax rates imposed by the source country, the taxpayer will be granted a deemed credit at residence that is already fixed in the specific clause. Additionally, contingent clauses can also be designed to prevent this undesired outcome (Brooks 2009, 561).

Other similar clauses are configured to condition their application on whether the relief provided at source exists due to economic development promotion $^{11}$. For instance, Article 22.3 of the tax treaty signed between Panama and Vietnam states (emphasis added):

For the purposes of paragraphs 1 and 2 of this Article, the income tax paid in a Contracting State shall be deemed to include the tax which would have been payable in the other Contracting State but for the exemption or reduction of tax granted under an incentive regime recognized by the laws and legislation of that Contracting State designed to promote economic development.

When compared to the previously mentioned clause that did not contain it, the inclusion of this nuance is fairly minor. Although the delimitation of the measures that promote economic development is left unaddressed, a statement by the source state that the tax incentive measure is aiming at the promotion of economic growth would probably suffice.

Another (more relevant) variation of these open clauses would apply only to specific items of income listed in the tax sparing clause ${ }^{12}$. For instance, Article 24.4 of the tax treaty signed between Cuba and Spain states (emphasis added):

Where a resident of Spain derives items of income referred to in Articles 7, 10, 11 and 12 of this Convention which, under the provisions thereof, may be taxed in Cuba, Spain shall allow, as a deduction from the tax due - as a tax credit - the amount that would

\footnotetext{
${ }^{11}$ See the tax treaties of Cuba (with China and Vietnam), Panama (with Vietnam), and Uruguay (with Vietnam).

${ }^{12}$ See the tax treaties of Cuba (with Austria and Spain). It is noteworthy that all tax sparing clauses negotiated by Cuba fit under the contingent "open" clause category.
} 
have been payable in Cuba in respect of a similar tax in the same fiscal period but for the legal provisions concerning tax exemption, relief, deduction or any other type of relief or reduction for a limited period under the relevant Cuban laws on tax matters for the promotion of foreign investments and economic development.

This particular clause raises an additional issue regarding the interaction of the said notional credit with the credit rule embedded in the said tax treaty that is included in Article 24.2. This provision states that, in the case of Spain, the credit for taxes paid in Cuba shall not exceed that part of the income tax or capital tax as it was computed before the deduction is given that is attributable to the income or the capital that may be taxed in Cuba. Moreover, it states that, in Spain, double taxation shall be avoided following the relevant provisions of the laws of Spain that include a similar rule in its domestic corporate tax credit for foreign taxes ${ }^{13}$. As the above-copied tax sparing clause is envisaged in a separate provision (Article 24.4), is the notional credit it grants subject to the credit limit posed in Article 24.2. The answer to this query is relevant because the ordinary corporate income tax rate in Cuba amounts to $35 \%$ while the standard tax rate in Spain is $25 \%$. The wording of Article 24 seems to allow for an interpretation favoring the deduction of the entire amount of the deemed taxes in Cuba. Often, tax sparing clauses establish in their wording that the deemed credit being granted is connected to the tax credit provision present in the $\operatorname{article}^{14}$, yet this terminology is missing in the tax treaty signed between Spain and Cuba. Additionally, the aim of the provision that is specifically to prevent the offset of tax savings obtained in Cuba through tax incentives would be fully realized. Notwithstanding, it would be naïve to ignore that Spain is consistent in negotiating tax treaties granting a limited credit. Hence, most probably, a taxpayer deducting the entire amount of taxes spared beyond the amount that would have been paid in Spain would face a significant risk of being assessed by the tax authorities.

\footnotetext{
${ }^{13}$ See Article 31.1.b) of the Spanish Corporate Income Tax Law (Ley 27/2014, de 27 de noviembre, del Impuesto sobre Sociedades).

${ }^{14}$ For instance, Art. 23.3 of the tax treaty signed between Cuba and China states: "For the purpose of paragraphs 1 and 2 of this Article, the tax not paid in a Contracting State by virtue of the legal provisions regarding tax reductions [...]" (emphasis added). Clearly, the tax sparing deemed credit must respect the limits envisaged in Arts.23.1 and 23.2 of the said treaty.
} 
The last type of contingent open clause detected in the Latin-American tax treaty network is conditioned to an agreement between the contracting states to be effective. For instance, Article 23.1.a).iii) of the tax treaty signed between Argentina and Spain ${ }^{15}$ states that (emphasis added):

For the purposes of this paragraph, the tax effectively paid in the Argentine Republic shall be deemed to be the one which would have been paid in accordance with the Convention, if no reduction of or exemption from tax would have been applied under specific provisions for the promotion of industrial development which the Argentine Republic, under a previous agreement thereon between the Governments, may introduce in its tax law.

The wording of this clause is fairly odd as it gives the impression that the introduction of tax incentives in the domestic law of Argentina requires an agreement between this country and Spain. Once this unreasonable interpretation is discarded, it is quite clear that the requirement of an agreement concerns the scope and implementation of the tax sparing clause itself. Thus far, there is no available information on such an agreement -at least not on the official websites of the Spanish and the Argentinian tax administrations- which entails that the clause is currently "dormant" meaning that this contingent clause has no effect due to the lack of an agreement in that regard. The same issue may be predicated from the tax treaty signed between Argentina and Australia.

A similar clause was introduced in the tax treaty signed between Argentina and Canada in which Article 23.3 states (emphasis added):

For the purposes of subparagraph (a) of paragraph 1, tax payable in Argentina by a company which is a resident of Canada in respect of profits attributable to manufacturing activities or to the exploration or exploitation of natural resources carried on by it in Argentina shall be deemed to include any amount which would have been payable thereon as Argentine tax for any year but for an exemption from, or reduction of, tax granted for that year or any part thereof under specific provisions of Argentine legislation that the competent

\footnotetext{
${ }^{15}$ It is relevant to note that the tax treaty signed between Argentina and Spain also Includes a matching credit provision applicable to royalties that is listed below in section 3.2.
} 
authority of Canada agrees should be covered by this provision, and only to the extent that the said provisions have the effect of exempting or relieving a source of income for a period not in excess of ten years.

Here, a double limit constrains the scope of the clause. On the one hand, the incentive measures adopted by Argentina must be cleared by Australia for the tax sparing to be granted. On the other hand, the domestic incentive provisions of Argentina must extend their effect to a period not in excess of ten years irrespective of whether the Australian tax authorities consider the incentive to be eligible for tax sparing.

ii) The Latin-American tax treaty network also comprises contingent tax sparing clauses that grant a notional credit equivalent to taxes saved due to listed tax incentives, which will be referred to as restrained contingent clauses ${ }^{16}$. For instance, Article 22.2.b) of the tax treaty signed between Panama and Barbados states:

to the extent that a resident of Barbados may credit the taxes paid in Panama, Barbados shall include in the amount being credited the tax which is otherwise payable in Panama but has been spared, reduced or waived by Panama under the following provisions:

(i) Código Fiscal Artículo 701, literal d (Zona Libre de Colón y otras Zonas Libres), and its related decrees and regulations;

(ii) Decreto de Gabinete No. 36 de 17 de septiembre de 2003, Artículo 14 (Zonas Libres de Petróleo) and its related decrees and regulations (iii) Decreto Ley No. 6 de 10 de febrero de 1998, which approves the Agreement between the State and the Fundación Ciudad del Saber para el Establecimiento y el Desarrollo de la Ciudad del Saber Cláusula Quinta, literal D)y E), and its related decrees and regulations

(iv) Ley No. 41 de 20 de julio de 2004, Artículo 60 (Agencia del Área Económica Especial Panamá-Pacífico) and its related decrees and regulations

(v) Ley No. 41 de 24 de agosto de 2007, Artículo 21, and Decreto Ejecutivo No. 28 de 27 de marzo de 2009 del Ministerio de Comercio e Industria, Artículo 26 (Sedes de Empresas Multinacionales), and its related decrees and regulations

\footnotetext{
${ }^{16}$ Tax treaties of Brazil (with Japan) (this convention also includes a matching credit clause), Ecuador (with Uruguay), Panama (with Barbados), Venezuela (with Barbados and Malaysia), and Uruguay (with Ecuador).
} 
(vi) Ley No. 25 de 30 de noviembre de 1992, Artículo 27 (Zonas Procesadoras para la Exportación) and its related decrees and regulations

(vii) and Any other provision which may subsequently be made, granting an exemption which is agreed by the competent authorities of Panama and Barbados to be of a substantially similar character.

The majority of restrained contingent clauses establish that the adoption of new measures that are substantially similar would be covered by the clause, albeit conditioned to an agreement by the contracting states confirming this. Indeed, the tax treaty between Panama and Barbados referred to above contains such a clause in fine (vii). It is relevant to note that this remark refers to the adoption of new measures but not to the modification of the measures listed in the provision. In this regard, the main interpretative issue concerning these clauses refers to the question of whether the laws listed therein should be understood as comprising their content when the tax treaty entered into force or should be read following the content existing at the time the clause is to be applied. The query is relevant because, if subsequent modifications can be included and would be covered by the relevant tax sparing clause, then the source state has broader room for maneuvering in defining its range of tax incentives that would not be offset by taxation at residence.

\section{Matching credit clauses}

Matching credit clauses grant a notional credit based on a specific percentage that applies to passive income streams and, hence, it is not linked to the specificities of any domestic tax incentive. The following chart compiles all of the matching credit clauses that are present in the LatinAmerican tax treaty network. It amounts to a total of 32 clauses, 19 of which correspond to the Brazilian tax treaty network. The matching credit rate per item of income is reflected alongside the limitation on tax rates to the source state in brackets: 


\begin{tabular}{|l|l|l|l|l|}
\hline Tax treaty & $\begin{array}{l}\text { Granting } \\
\text { State }\end{array}$ & Dividends & Interests & Royalties \\
\hline Argentina - Finland & Finland & - & - & $15 \%(10 \%)^{17}$ \\
\hline Argentina - Germany & Germany & $20 \%(15 \%)$ & $15 \%(10 / 15 \%)$ & $20 \%(15 \%)^{18}$ \\
\hline Argentina - Italy & Italy & $15 \%(15 \%)$ & $20 \%(0 / 20 \%)$ & $20 \%(10 / 18 \%)$ \\
\hline Argentina - Spain & Spain & - & - & $15 \%(10 \%)^{19}$ \\
\hline Bolivia - Germany & Germany & - & $20 \%(0 / 15 \%)$ & $20 \%(15 \%)$ \\
\hline Brazil - Austria & Austria & $25 \%(15 \%)$ & $25 \%(0 / 15 \%)$ & $25 \%(10 / 15 / 25 \%)$ \\
\hline Brazil - Canada & Canada & $25 \%{ }^{20}(15 \%)$ & $20 \%(10 / 15 \%)$ & $20 \%{ }^{21}(15 \%)$ \\
\hline Brazil - Czech Rep. & Czech Rep. & - & $25 \%(0 / 10 / 15 \%)$ & $25 \%(15 / 25 \%)$ \\
\hline Brazil - Denmark & Denmark & - & $25 \%(0 / 15 \%)$ & $25 \%(15 / 25 \%)$ \\
\hline Brazil - Ecuador & Bilateral & $25 \%(15 \%)^{22}$ & $25 \%(15 \%)$ & $25 \%(15 \%)^{23}$ \\
\hline Brazil - Finland & Finland & $15 \%(10 \%)$ & $25 \%(0 / 15 \%)$ & $25 \%(10 / 15 / 25 \%)$ \\
\hline Brazil - France & France & $20 \%(15 \%)$ & $20 \%(0 / 10 / 15 \%)$ & $20 \%(15 \%)^{24}$ \\
\hline Brazil - Hungary & Hungary & $25 \%(15 \%)$ & $25 \%(0 / 10 / 15 \%)$ & $25 \%(15 / 25 \%)$ \\
\hline Brazil - India & Bilateral & - & $25 \%(0 / 15 \%)$ & $25 \%(15 \%)^{25}$ \\
\hline Brazil - Italy & Brazil & $25 \%(15 \%)$ & - & - \\
\hline Brazil - Italy & Italy & $25 \%(15 \%)$ & $25 \%(0 / 15 \%)$ & $25 \%(15 / 25 \%)$ \\
\hline Brazil - Japan & Japan & $25 \%(12,5 \%)$ & $20 \%(0 / 12,5 \%)$ & $25 \%{ }^{26}(12,5 / 15 \%)$ \\
\hline Brazil - Korea & Bilateral & $20 \% / 25 \%$ & $20 \%(0 / 10 / 15 \%)$ & $20 \%(15 / 25 \%)$ \\
\hline & & $(15 \%)^{27}$ & & \\
\hline
\end{tabular}

\footnotetext{
${ }^{17}$ Only royalties referred to the use of or the right to use computer software, any patent, trade mark, design or model, plan, secret formula or process; for the use of or the right to use industrial, commercial or scientific equipment; for information concerning industrial, commercial or scientific experience, or other intangible property; or from the rendering of technical services or of technical, scientific, administrative or similar assistance ${ }^{18}$ Only royalties referred to the use or the right to use patents, trademarks, designs or models, plans, secret formulae or processes; or for information concerning industrial, commercial or scientific experience.

${ }^{19}$ Only provided such royalties are paid by a company that is a resident of the Argentine Republic and does not control, directly or indirectly, more than $50 \%$ of the capital of or is controlled in the same manner by a company that is a resident of a third State.

${ }^{20}$ Additional tax on companies other than Canadian corporations applicable to a resident of Brazil that has a permanent establishment in Canada.

${ }^{21}$ Royalties other than those arising from the use of or the right to use trademarks.

${ }^{22}$ In cases other than those concerning dividends paid by a company resident of a Contracting State to a company resident of the other Contracting State owning more than $10 \%$ of the capital of the paying company that are taxable in the first-mentioned Contracting State according to the provisions of this Convention as these shall be exempt from tax in the other Contracting State.

${ }^{23}$ Royalties other than those arising from the use of or the right to use trademarks.

${ }^{24}$ Royalties other than those arising from the use of or the right to use literary, artistic, or scientific works, including cinematograph films as well as films or tapes for television or radio broadcasting as long as such films or tapes are produced by residents of either Contracting State, and royalties arising from the use of a trademark. ${ }^{25}$ Royalties other than those arising from the use of or the right to use trademarks.

${ }^{26}$ Royalties other than those arising from the use of or the right to use trademarks.

${ }^{27} 25 \%$ in the case of dividends referred to in paragraph 2 of Article $10 ; 20 \%$ in the case of profits referred to in paragraph 5 of Article 10, i.e. "where a resident of Korea has a permanent establishment in Brazil, this permanent establishment may be subject to a tax withheld at source in accordance with Brazilian law. However, such a tax
} 


\begin{tabular}{|l|l|l|l|l|}
\hline Brazil - Luxembourg & Luxembourg & $25 \%^{28}(15 \%)$ & $20 \%(0 / 15 \%)$ & $25 \%(15 \%)^{29}$ \\
\hline Brazil - Netherlands & Netherlands & $\begin{array}{l}25 \%^{30} / 20 \% \\
(15 \%)\end{array}$ & $20 \%(0 / 10 / 15 \%)$ & $\begin{array}{l}25 \%(25 \%)^{31} / 20 \% \\
(15 \%)^{32}\end{array}$ \\
\hline Brazil - Norway & Norway & $25 \%(15 \%)$ & $25 \%(0 / 15 \%)$ & $25 \%(15 / 25 \%)$ \\
\hline Brazil - Philippines & Bilateral & $25 \%(15 / 25 \%)$ & $25 \%(0 / 10 / 15 \%)$ & $25 \%(15 / 25 \%)$ \\
\hline Brazil - Slovak Rep. & Slovak Rep. & - & $25 \%(0 / 10 / 15 \%)$ & $25 \%(15 / 25 \%)$ \\
\hline Brazil - Spain & Bilateral & - & $20 \%(0 / 10 / 15 \%)$ & $25 \%(10 / 15 \%)$ \\
\hline Brazil - Sweden & Sweden & $25 \%(15 \%)^{33}$ & $20 \%(0 / 15 / 25 \%)$ & $25 \%(15 / 25 \%)$ \\
\hline Chile - Switzerland & Switzerland & $15 \%^{34}(15 \%)$ & & - \\
\hline $\begin{array}{l}\text { Colombia } \\
\text { Switzerland }\end{array}$ & Switzerland & $10 \%(15 \%)^{35}$ & - & $20 \%(15 \%)$ \\
\hline Ecuador - Germany & Germany & - & $20 \%(0 / 10 / 15 \%)$ & - \\
\hline Mexico - France & France & $\begin{array}{l}5 \%(5 \%)^{36} / 15 \% \\
(15 \%)^{37}\end{array}$ & - & - \\
\hline Mexico - Italy & Italy & $15 \%(15 \%)^{38}$ & - & - \\
\hline Mexico - Korea (Rep.) & Korea (Rep.) & $15 \%(0 / 15 \%)^{39}$ & - & $15 \%(10 \%)$ \\
\hline Mexico - Singapore & Singapore & $15 \%(0 \%)$ & - & $10 \%(10 \%)$ \\
\hline Uruguay - Germany & Germany & $5 \%(5 \%)^{40}$ & $10 \%(0 / 10 \%)$ & \\
\hline
\end{tabular}

cannot exceed $15 \%$ of the gross amount of the profits of that permanent establishment after the payment of the corporate tax related to such profits".

${ }^{28}$ Only applicable to dividends if the beneficial owner is a company that holds directly at least $10 \%$ of the capital of the company paying the dividends.

${ }^{29}$ Royalties other than those from the use or the right to use any trademarks, cinematograph films, or films or tapes for television or radio broadcasting.

${ }^{30}$ If the dividends are paid to a company of the Netherlands holding at least $10 \%$ of the voting capital of the Brazilian company.

${ }^{31}$ Only other than those arising from the use of or the right to use trademarks if they are paid to a company of the Netherlands holding directly or indirectly at least $50 \%$ of the voting capital of a Brazilian company provided that they are not deductible in the determination of the taxable income of the company paying the royalties.

${ }^{32}$ Royalties other than those arising from the use of or the right to use trademarks.

${ }^{33}$ Only dividends paid by a company resident in Brazil to a company (excluding a partnership) resident in Sweden for which dividends are not exempt from tax in Sweden under paragraph 2 of the elimination of double taxation article.

${ }^{34}$ The gross dividend, specifically, the base over which the percentage is to be applied will be increased by $15 \%$.

${ }^{35}$ Only applicable if Colombia exempts a company on the tax of its profits.

${ }^{36}$ If the beneficial owner is a company that holds directly or indirectly at least $10 \%$ of the capital of the company paying the dividends.

${ }^{37}$ Applicable if the shareholder holds a participation ranging between more than $10 \%$ and $50 \%$.

${ }^{38}$ Only provided that the profits out of which such dividends are paid are derived principally from business carried on in Mexico.

${ }^{39}$ Only applicable if Mexico does not impose a tax on dividends paid by companies resident in Mexico or exempts those dividends from tax.

${ }^{40}$ Only if the beneficial owner is a company (other than a partnership) which holds directly at least $10 \%$ of the capital of the company paying the dividends and Germany applies the credit method to eliminate double taxation in accordance with Article 22.1.e).bb). 
The chart shows that the spread between the effective taxation at source and the matching credit can be as high as $25 \%$, for instance, in the FinlandBrazil tax treaty that exempts at source the interest arising in Brazil and paid to (i) the State of Finland or a local authority thereof; (ii) the Bank of Finland or ; (iii) any agency (including a financial institution) wholly owned by the Government of Finland, a statutory body, or a local authority thereof (Article 11.3.a) but grants a 25\% matching credit on interest (article 22.2.e). Note that this spread is generated by the tax treaty limitations on source taxation, however, the spread can be also impacted by the rate imposed at the domestic level. Still, in the context of the Finland-Brazil tax treaty, Article 10.1 permits the source state to apply a rate of $10 \%$ to dividend payments. As the matching credit rate applicable to this item of income is $15 \%$, it would be expected, in principle, that the spread amounts to $5 \%$. Notwithstanding, Brazil does not apply withholding taxes to dividend payments. Hence the actual spread is $15 \%$, meaning that the dividends obtained by a Finnish investor will not be subject to source taxation in Brazil while a $15 \%$ tax credit may be applied against the Finnish corporate income tax.

Holland and Vann explain that matching credit clauses are usually confined to passive income because a relative limit is imposed on source taxation, and the credit method is often adopted even in cases of double tax treaties opting for exemption as a relief method -as a result of switch over or subject-to-tax clauses. Thus, it is a relatively straightforward matter to compare the rate of the notional credit with the limit on source country taxation (Holland and Vann 1998, 27). However, there is one tax treaty containing a matching credit clause in the Latin-American tax treaty network regarding the taxation business profits, specifically, the one signed between Argentina and Italy. Article 24.5 states that, if the Argentine tax on profits of enterprises is wholly or partly uncollected during a specified period, such tax shall be deemed paid to a limit of $15 \%$ of such profits.

As stated above, the functioning of matching credit clauses is much simpler than that of contingent tax sparing, although specific interpretation problems may also arise. For instance, in some cases, the tax sparing clause refers to dividends, interest, and/or royalties without making an express reference to a specific definition. The problem may be exemplified with the 
clause included in Article 23.3 of the tax treaty signed between Argentina and Germany which states the following:

(a) For the purposes of computing the credit referred to in paragraph 2, the Argentine tax shall be deemed to be: $20 \%$ of the gross amount of dividends and royalties included in subparagraph (b) of paragraph 2 of Article 12;

(b) $15 \%$ of the gross amount of interest.

While there is a straightforward reference to the definition of the concept of royalties embedded in Article 12.2.b) -referring to the use or the right to use patents, trademarks, designs or models, plans, secret formulae or processes, or for information concerning industrial, commercial or scientific experience- there are no references to the definitions of the terms "dividends" and "interest". Hence, the definitions embedded in Articles 10.3 and 11.4 of the tax treaty are, in principle, not applicable as these provisions restrain their scope to Articles 10 and 11 respectively, due to the use of the formula "The term (dividends / royalties) as used in this Article, means [...]" and therefore exclude their use in other articles of the convention. Notwithstanding, Article 3.2 requires that domestic law definitions will be taken into account to fulfill the meaning of treaty terms "unless the context otherwise requires". This is an indeterminate clause that could lead to the use of the already existing definitions present in said Articles 10.3 and 11.4 that were ultimately agreed by the parties. They are present in the convention and were probably limiting their scope since the parties were following the definitions posed in the OECD or the UN models (Avery Jones, sec.5.1.2.4.2.6). In any case, this interpretation issue impacts the scope of the clauses that leave the question open.

For instance, the issue does not arise in clauses such as the one included in Article 23.4 of the tax treaty signed between Brazil and Italy in which the remission to the definitions of the said concepts is clearly expressed in the matching credit clause:

For the deduction mentioned in paragraph 2 of this Article Brazilian tax shall always be considered as having been paid at the rate of 25 percent of the gross amount:

(a) of the dividends as defined in paragraph 4 of Article 10;

(b) of the interest as defined in paragraph 4 of Article 11, and 
(c) of the royalties as defined in paragraph 4 of Article 12.

Another interpretative issue that is of interest in the context of matching credit clauses refers to the limitation of their amount due to the adoption of an ordinary credit rule in the applicable tax treaty. The issue arose in the Canadian Société Générale Valeurs Mobilieres case ${ }^{41}$ that was commented on by Duff (2018). The matching credit clause of the tax treaty signed between Brazil and Canada refers to gross amounts to calculate the deemed credit to be credited at residence. In contrast, the ordinary credit clause to which the matching credit is linked limits the credit to the Canadian tax otherwise payable on the net interest income -instead of gross income- earned in Brazil. The discussion was regarding the interpretation of the said clause that was envisaged in Article 22.2 stating (emphasis added):

[...] Canada shall allow as a deduction from the tax on the income of that person, an amount equal to the income tax paid in Brazil, including business-income tax and non-business-income tax. The deduction shall not, however, exceed that part of the income tax as computed before the deduction is given, which is appropriate to the income which may be taxed in Brazil.

The taxpayer considered that the word "appropriate" entails that Article 22.3 grants a matching credit on the gross amount of the income. On the other hand, the tax authorities consider that the said term contemplates a logical connection between the Canadian tax payable by the taxpayer on the Brazil bond income and the total Canadian tax paid on its worldwide income ${ }^{42}$. The court instead focused on the phrase "income tax as computed before the deduction is given" and emphasized that this is a reference to Canadian income tax which "would undoubtedly been known to the drafters that Canadian income tax is calculated net of applicable expenses. In order to depart from this basic concept of Canadian tax law, clear language to that effect would have been required" ${ }^{43}$. The case clearly shows that matching credit clauses must be contrasted with the ordinary credit clauses they are often connected to in order to ascertain their real scope.

\footnotetext{
${ }^{41}$ Société Générale Valeurs Mobilieres Inc. v. Her Majesty the Queen, 2016 TCC 131, 2017 FCA 3.

${ }^{42}$ Id., par.21.

${ }^{43}$ Id., par.41.
} 
A major topic of concern in what relates to the functioning of matching credit clauses is whether their enforcement should take place regardless of the taxation level at the state of source. The issue was raised in the context of the tax treaty signed between Brazil and France (1971) in the Natexis case $^{44}$. An administrative instruction issued on December $8,1997,{ }^{45}$ by the French tax authorities denied the applicability of the matching credit clause present in the said tax treaty if no taxes were levied in Brazil. The instruction overruled a previous one published in 1972 that stated the possibility to enjoy the effects of the matching credit clause even if there was no taxation in Brazil ${ }^{46}$. The terminology of the matching credit clause envisaged in Article XXII.2.d) is as follows:

As regards income referred to in Articles X, XI and paragraph 2(c) of Article XII, the Brazilian tax shall be considered as being levied at a minimum rate of $20 \%$.

Natexis, a French financial institution, considered that the French authorities' interpretation was contrary to the tax treaty and requested the Ministry of Economy, Finance and Industry to revoke it. As the claim was answered in the negative, Natexis resorted to the French courts. A decision was given by the Supreme Administrative Court that confirmed the legality of the administrative instruction thereby neglecting the right of Natexis to enjoy the effects of the matching credit clause. This was due to the fact that no taxes were levied in Brazil on the interest income obtained by the financial institution due to a domestic incentive measure.

The main argument raised in the case was that the matching credit clause could only apply when the conditions of Article XXII.2.c) -the section preceding the matching credit clause- are met. The wording of this provision is as follows (emphasis added):

As regards income referred to in Articles X, XI, XII, XIII, XIV, XVI and XVII, which has borne Brazilian tax in accordance with the provisions of these Articles, France shall allow its residents receiving

\footnotetext{
${ }^{44}$ Conseil d'État, 26 July 2006, Société Natexis Banques Populaires, n. 284930.

${ }^{45}$ Instruction No. 14 A-7-97.

${ }^{46}$ Instruction No. 14 B-17-72.
} 
such income a tax credit corresponding to the amount of Brazilian tax which has been paid, within the limits which the French tax establishes on such income.

Hence, as no taxes were effectively levied in Brazil, the matching credit clause should not apply because both clauses -the matching credit and the one allowing the tax credit- cannot be enforced independently from each other. Here, the issue revolves around the interpretation of the word "borne" that, according to the French Supreme Administrative Court, would not admit the fictive levy that the matching credit clause entails but only taxes effectively paid by the taxpayer. This has been a much-criticized decision because of different reasons.

The first is the stringent interpretation of the expression "has borne" -in French supporté and incidido in Portuguese. The difference of these concepts is similar to that of subject to tax and liable to tax that is present in Article 4 of the OECD Model Tax Convention per Ferreira and Marinho $(2013,411)$. This that led to the restriction of the scope of the matching credit clause without any apparent reason.

Second, the interpretation made by the French tax authorities for the 1997 administrative instruction superseded that of 1972 which allowed the matching credit clause to apply even in the event of no taxation in Brazil. This instruction followed the conclusion of the tax treaty signed between Brazil and France in 1971 and was in accordance with the intention of both signatory parties. However, without any amendments to the tax treaty or any mutual agreement in place, the French tax authorities unilaterally decided to override its content (Santos 2015, 24; Silva 2012, 235).

Third, it is contradictory to the very rationale of the matching credit clause as it ignores Brazil's unilateral decision of not taxing these interests at the domestic level. As stated above in section 2, the purpose of including matching credit clauses in conventions is to provide the opportunity to the source state to not tax an item of income in a way that is meaningful to attract investment, i.e. not allowing the residence country to tax the income back (Ferreira and Marinho 2013, 405).

Fourth, it seems quite illogical and somewhat disproportionate that the clause would not apply if no taxes are levied, but an effective taxation of $0,01 \%$-just to name a fairly low figure- would effectuate a matching credit clause granting a credit equal to $20 \%$ of the received income. An 
interpretation leading to such a disparate sudden increase cannot be regarded as reasonable.

Notwithstanding, in a posterior decision regarding the same taxpayer this time by the name of Natixis $-{ }^{47}$ the Conseil d'État gives another twist to its odd interpretation of matching credit rules (Baker 2015; Julien 2017, sec.9.4.2). The court considered that the matching credit clause included in the treaty signed with China applies even if Chinese taxes were not paid on the income. Yet, it also affirmed that the matching credit clause included in the tax treaty signed with Argentina requires the taxpayer to specify the Argentinian tax rule pursuant to which the interest income was untaxed. Thus, it is requiring the taxpayer to bear the burden of the proof in order to benefit from a matching credit in France. This peculiar understanding of matching credit clauses makes it extremely difficult to determine whether such provisions will be applicable in a specific case and, if so, which requirements the taxpayer must meet to benefit from them.

The necessity for taxation in the State of source for a matching credit clause to be applicable was also raised in Spain in the Laboratorios Indas case $^{48}$. The facts concerned an interest payment obtained by a Spanish entity that was borne by a permanent establishment located in Madeira (Portugal) of a company resident in Brazil. The taxpayer applied the tax treaty signed between Brazil and Spain that contains a matching credit clause granting a deemed credit equal to a tax rate of $20 \%$ applicable to interest payments. Specifically, Article 23.2 reads as follows:

For the purpose of the deduction mentioned in paragraph 1, the tax on interest and royalties shall always be considered as having been paid at the rates of $20 \%$ and $25 \%$, respectively.

The Spanish National Court (Audiencia Nacional) decided against the taxpayer for two reasons. On the one hand, it considered that the tax treaty signed between Brazil and Spain was not applicable, however, the one signed between Portugal and Spain was relevant since the interests borne by a permanent establishment should be considered as arising where the

\footnotetext{
${ }^{47}$ Conseil d'État, 25 February 2015, SA Natixis, n. 366680.

${ }^{48}$ SAN November $23^{\text {rd }}, 2009$ (rec. 382/2007), ECLI: ES:AN:2009:5554. The decision was upheld by the Spanish Supreme Court in STS April 16 $6^{\text {th }}$, 2012 (rec. 435/2010), ECLI: ES:TS:2012:2353, yet the argument concerning the matching credit was not addressed.
} 
permanent establishment is located ${ }^{49}$. On the other hand, concerning the applicability of the matching credit clause, the court stated that its nature is that of a rebuttable presumption (iuris tantum) clause and, because the tax authorities proved that the income was not taxed abroad, the presumption no longer applies and thus the clause should not apply ${ }^{50}$. The reasoning behind the invention of an additional requirement asserted by the court for the clause to be applied remains unknown as no further argumentation was provided.

Irrespective of the fact that the decisions by the French Supreme Administrative Court and the Spanish National Court are inconsistent with the aim and wording of the tax treaties under discussion, the fact is that the risk of treaty override exists and must be taken into consideration in the context of tax sparing rules. This factor is perhaps even more relevant in the post-BEPS world in which double non-taxation outcomes -even if expressly wanted by the parties-are fairly problematic, as shown in section 4.

\section{Closing remarks on the tax sparing clauses present in the Latin-American tax treaty network}

The examination of the tax sparing clauses that are in force in the LatinAmerican tax treaty network leads to several relevant conclusions. The phenomenon of tax sparing and the consequent double non-taxation it entails cannot be considered as widespread as only 50 clauses remain applicable out of 252 conventions currently in force. Moreover, the classic form of tax sparing, i.e. the contingent variant, is only present in 18 tax treaties. Moreover, the usual thought that tax sparing clauses refer to specific incentives must be put into question, at least in the Latin-American region since only six clauses are designed in this manner. As shown, matching credit clauses have more relevance in Latin-America than contingent clauses mainly due to the treaty policy of Brazil, which concentrates most of these clauses. Clearly, it cannot be said that tax sparing is a common feature of Latin-American countries but of specific countries and, in some cases, during a specific period.

\footnotetext{
${ }^{49}$ See art.11.8 of the tax treaty signed between Brazil and Spain and Art.11.5 of the tax treaty signed between Portugal and Spain.

${ }^{50}$ See SAN November 23 ${ }^{\text {rd }}$, 2009 (rec. 382/2007), ECLI: ES:AN:2009:5554, FD $4^{\circ}$ in fine.
} 
It is also significant that there are only three tax sparing clauses signed between countries in the region ${ }^{51}$. Therefore, there is a clear will to become attractive to countries outside Latin-America. Bilateral tax sparing clauses are in force in only 15 tax treaties. Both signatory countries agree to grant tax sparing treatment either bilaterally or through the use of different clauses for each country ${ }^{52}$. For just two tax treaties, the country granting the tax sparing is a Latin-American one ${ }^{53}$, mainly due to the position of LatinAmerican countries as capital importing jurisdictions.

The analysis is inconclusive regarding the impact of the 1998 OECD Report on Tax Sparing on the policy decisions of OECD and non-OECD members towards a decrease in the use of these clauses (cfr. Andrade 2020, 14; Kofler and Pötgens 2020, sec. 1.1.2.3). On the one hand, it must be realized that 17 clauses in force were negotiated and adopted after the said report was published, amounting for almost one-third of the total clauses currently in force, which is not a figure as low as would be expected. On the other hand, none of the countries that adopted them are OECD members. Hence, the weight of the report in terms of its influence on the policy of these countries must be relativized. For instance, Mexico abandoned its tax sparing policy after 1997 right before the said report was published and some years after its accession to the OECD in 1994. Brazil also long ago abandoned its tax sparing -or to be more precise, its matching credit- policy as the latest tax treaties in force to incorporate one of these clauses is the one signed with Finland that entered into force in 1996.

Additionally, it must be emphasized that the importance of tax sparing has diminished over time due to the increasing territorial features of many countries that would leave certain items of income exempted, thus leaving the source state with the decision on how to tax the income (Brooks 2009, 530). For instance, Spain is the country with the broadest tax treaty network in the world with the Latin-American region. In its corporate income tax to its tax residents, it includes a participation exemption regime that applies irrespective of the method chosen in the applicable tax treaty. This regime

\footnotetext{
${ }^{51}$ Tax treaties of Brazil with Ecuador, Cuba with Venezuela, and Ecuador with Uruguay.

${ }^{52}$ Regarding contingent tax sparing clauses, see the tax treaties of Cuba (with Qatar, China, Russia, Vietnam), Ecuador (with Uruguay), Panama (with Barbados and Vietnam), Uruguay (with Ecuador and Vietnam), and Venezuela (with Malaysia). Concerning matching credit clauses, see the tax treaties of Brazil (with Ecuador, India, Italy, Korea, Philippines, and Spain).

${ }^{53}$ See the tax treaties of Venezuela (with Barbados and Cuba).
} 
would leave exempted dividend income and capital gains derived from the alienation of qualifying shares ${ }^{54}$. Moreover, Spain grants an exemption to income attributable to foreign permanent establishments of Spanish companies $^{55}$. Lastly, there is a holding regime (ETVE) that would leave exempted the dividend distributions by a qualifying entity to the nonresident shareholders if the dividend income derives from income previously obtained from non-resident entities to which the participation exemption regime applies ${ }^{56}$. The applicability of these regimes in the LatinAmerican context leads to a bolstering of the effects of tax incentives granted by the region to Spanish-based investors or even investors abroad channeling investments through Spain.

\section{Conclusion}

Developing countries frequently grant corporate income tax incentives to attract foreign direct investment that ultimately contributes to their economic growth. To secure the effectiveness of these measures at a crossborder level in the context of jurisdictions that eliminate double taxation through the credit method, tax sparing clauses grant a notional credit at residence -even if no or lower taxes were paid at source. This is to prevent the residence country from taxing that income thereby allowing the investor to retain the tax spared by the source country. Several arguments for and against tax sparing have been examined from both the host country's perspective and the home country. The appropriateness and effectiveness of these measures is far from being clear. Notwithstanding, what seems unequivocal is that tax sparing is a relevant expression of the fiscal sovereignty of those states that demand the adoption of the clause in their double tax treaty network and that several developing countries consider this instrument as a key element of their tax treaty negotiation policy.

\footnotetext{
${ }^{54}$ To opt for the regime, a 5\% participation on the distributing entity or a purchase value of the shares of at least $€ 20$ million is needed combined with a rule requiring non-resident distributing entities to be taxed at a minimum of $10 \%$ nominal tax rate; this requirement is automatically cleared if the country of residence has signed a tax treaty with Spain, which will be often the case in the Latin-American region. See Art.21 Ley 27/2014, de 27 de noviembre, del Impuesto sobre Sociedades (hereinafter Spanish Corporate Income Tax Law).

${ }^{55}$ See art.22 of the Spanish Corporate Income Tax Law

${ }^{56}$ ETVE stands for Entidades de Tenencia de Valores Extranjeros, meaning entities holding foreign participations. See Arts.108 of the Spanish Corporate Income Tax Law.
} 
The Latin-American tax treaty network has been examined in order to ascertain the actual impact of tax sparing clauses in a specific region. Out of a total of 250 tax treaties, 70 tax sparing clauses were found, although just 49 clauses are still enforceable and were subject to analysis. Additionally, a reference to the threat that $\mathrm{CFC}$ rules and the adoption of an income inclusion rule proposed by the OECD Global Anti-Base Erosion Proposal (GloBE) pose to tax sparing rules was pinpointed. Only time will tell whether this is the beginning of the end of tax sparing clauses and, more broadly, of tax incentives to foreign direct investment.

\section{Acknowledgements}

The author would like to thank Yvette Lind, Óscar Munévar, and the anonymous peer reviewers for their valuable comments and suggestions as well as the participants in the Copenhagen Business School "Inequality within international taxation" conference held online on September the $14^{\text {th }}, 2020$.

\section{Funding}

The present contribution was partially drafted during a research stay at the Max Planck Institute in Munich and under the framework of the research project DER2017-85333-P titled "Post-BEPS international taxation. Are the new rules and proposals suitable for every jurisdiction?" funded by the Spanish Ministry of Economy. The author acknowledges and appreciates this institutional support.

\section{References}

\section{Case law}

FR: Conseil d'État, 26 July 2006, Société Natexis Banques Populaires, n. 284930, ECLI:FR:CESSR:2006:284930.20060726.

FR: Conseil d'État, 25 February 2015, SA Natixis, n. 366680, ECLI:FR:CESSR:2015:366680.20150225.

NZ: Lin v. Commissioner of Inland Revenue [2017] NZHC 969.

NZ: Lin v. Commissioner of Inland Revenue [2018] NZCA 38.

NZ: Lin v. Commissioner of Inland Revenue [2018] NZSC 54.

SP: SAN November 23 ${ }^{\text {rd }}, 2009$ (rec. 382/2007), ECLI:ES:AN:2009:5554.

SP: STS April 16 ${ }^{\text {th }}, 2012$ (rec. 435/2010), ECLI:ES:TS:2012:2353. 


\section{Official documents}

FR: Instruction n. 14 A-7-97.

FR: Instruction n. 14 B-17-72.

\section{Literature}

Andrade, Betty. 2020. A Look at Tax Sparing Clauses in the 21st Century as Tools for the Implementation of Tax Incentives from the Perspective of Developing Countries. International Tax Studies 7: 1-26.

Arnold, Bryan J. 2018. The relationship between controlled foreign corporation rules and tax sparing provisions in tax treaties: New Zealand case. Bulletin for international taxation 72 (7): 430-438.

Ashiabor, Hope. 1998. Tax Sparing: A Timeworn Mechanism in Australia's Bilateral Treaties with Its Trading Partners in Southeast Asia. International Tax Journal. 24: 67-98.

Avery Jones, John F. 2019. Treaty Interpretation. In R. Vann (ed.). Global Tax Treaty Commentaries. Amsterdam: IBFD.

Azémar, Céline and Delios, Andrew. 2007. The tax sparing provision influence: a credit versus exempt investors analysis. Department of Economics, University of Glasgow: 1-31.

Azémar, Céline and Dharmapala, Dhammika. 2019. Tax sparing agreements, territorial tax reforms, and foreign direct investment. Journal of Public Economics 169: 89-108.

Azémar, Céline, Desbordes, Rodolphe and Mucchielli, Jean-Louis. 2007. Do tax sparing agreements contribute to the attraction of FDI in developing countries? International Tax and Public Finance 14 (5): 543-562.

Baker, Philip. P. 2015. Re SA Natixis: No 366680. International tax law reports 18: 103-137.

Barker, William B. 2007. An international tax system for emerging economies, tax sparing, and development: it is all about source. University of Pennsylvania Journal of International Law 29 (2): 349-390.

Blum, Daniel W. 2019. The Proposal for a Global Minimum Tax: Comeback of Residence Taxation in the Digital Era?: Comment on Can GILTI + BEAT = GLOBE? Intertax 47 (5): 514-522.

Brauner, Yariv. 2013. The future of tax incentives for developing countries. In Yariv Brauner and Miranda Stewart (eds.). Tax, Law and Development. Cheltenham: Edward Elgar Publishing, 25-56. 
Brooks, Kim. 2009. Tax sparing: a needed incentive for foreign investment in low-income countries or an unnecessary revenue sacrifice? Queen's Law Journal 34 (2): 505-564.

Brown, Karen B. 2002. Missing Africa: Should US International Tax Rules Accommodate Investment in Developing Countries? University of Pennsylvania Journal of International Economic Law 23 (1): 45-84.

Byrne, Peter D. 1998. Treaty Prospects in Latin America. Tax Notes International 16 (1): 45-52.

Coelho, Christiane. 2008. Tax Sparing and Brazil's Tax Treaties. Tax Notes International 51 (8): 685-697.

Dagan, Tsilly. 2000. The tax treaties myth. New York University Journal of International Law and Politics 32 (4): 939-996.

Darcy, John 1986. The Effect of Tax-Sparing on United States Business in China. University of San Francisco Law Review 21 (2-3): 393-417.

Duff, David G. 2018. Limitation on Elimination of Double Taxation under the Canada-Brazil Income Tax Treaty. In Michael Lang and et al. (eds.). Tax treaty case law around the globe: 2017. Amsterdam: IBFD, 333-342.

Elliffe, Craig. 2019. New Zealand: Lin v. Commissioner of Inland Revenue (High Court and Court of Appeal of New Zealand). In Eric Kemmeren et al. (eds.). Tax treaty case law around the globe: 2018. Amsterdam: IBFD, 339-361.

Englisch, Joachim and Becker, Johannes. 2019. International effective minimum taxation - the GLOBE proposal. World tax journal 11 (4): 483529.

Ferreira, Vanessa A. and Marinho, Anapaula T. 2013. Tax Sparing and Matching Credit: From an Unclear Concept to an Uncertain Regime. Bulletin for International Taxation 67 (8): 397-413.

Ferreira, Vanessa A. and Perdelwitz, Andreas. 2018. Tax Incentives and Tax Treaties In Madalina Cotrut and et al. (eds.). Tax Incentives in the BEPS Era. Amsterdam: IBFD, 173-205.

Hattingh, Jonathan P. 2020. The relevance of BEPS materials for tax treaty interpretation. Bulletin for international taxation 74 (4/5): 179-196.

Haynes, Duncan E. 1971. Tax treaties and tax neutrality: a proposal being considered by Indonesia. Minnesota Law Review 56 (5): 755-804. 
Hines Jr., James. 2000. Tax sparing and direct investment in developing countries. In James Hines Jr. (ed.). International Taxation and Multinational Activity. Chicago: University of Chicago Press, 39-72.

Holland, David and Vann, Richard J. 1998. Income tax incentives for investment. In Victor Thuronyi (ed.). Tax law design and drafting. Washington: International Monetary Fund, 2-9.

Holmes, Kevin J. 2018. New Zealand taxpayer not entitled to foreign tax credit for tax sparing granted to controlled foreign company. Asia-Pacific Tax Bulletin 24 (3): 1-2.

Hu, Tianlong and Li, Na. 2015. China Tax Treaty and Policy: Development and Updates. In Yariv Brauner and Pasquale Pistone (eds.). BRICS and the emergence of international tax coordination. Amsterdam: IBFD, 181229.

Julien, Rita. 2017. Elimination of double taxation. In Michael Lang et al. (eds.). The UN Model Convention and its relevance for the global tax treaty network. Amsterdam: IBFD, 209-260.

Kofler, Georg and Pötgens, Frank. 2020. Article 23 - Methods for Elimination of Double Taxation. Global Topics IBFD. IBFD Tax Research Platform (subscription-based database).

Kuźniacki, Blazej. 2015. The Need to Avoid Double Economic Taxation Triggered by CFC Rules under Tax Treaties, and the Way to Achieve It. Intertax 43 (12): 758-772.

Larkin, Barry 2020. What the world thinks of Pillar 2. Tax notes international 98 (2): 185-204.

Laurey, Damian. 2000. Reexamining US tax sparing policy with developing countries: The merits of falling in line with international norms. Virginia Tax Review 20 (2): 467-498.

Li, Jinyan. 2007. The rise and fall of Chinese tax incentives and implications for international tax debates. Florida Tax Review 8 (7): 669-712.

Li, Na. 2017. Tax Sparing: Use It, But Not as a Foreign Aid Tool. Intertax 45 (8): 546-555.

Li, Na. 2018. The Tax Sparing Mechanism and Foreign Direct Investment. Amsterdam: IBFD.

Liebman, Howard M. 1978. A Formula for Tax-Sparing Credits in the U.S. Tax Treaties with Developing Countries. American Journal of International Law 72 (2): 296-316. 
Long, Yi. 2018. Developments in China's Treaty Policy: Where is the Dragon Heading? Bulletin for international taxation 72 (9): 1-22.

Margalioth, Yotam. 2003. Tax competition, foreign direct investments and growth: using the tax system to promote developing countries. Virginia Tax Review 23 (1): 161-204.

Martin, William J. 1998. Treaty tax-sparing credits. Tax Management International Journal 27 (9): 444-465.

Martínez Laguna, Félix D. 2017. Abuse and Aggressive Tax Planning: Between OECD and EU Initiatives: The Dividing Line between Intended and Unintended Double Non-Taxation. World Tax Journal 9 (2): 189-246.

McDaniel, Paul R. 2003. The U.S. tax treatment of foreign source income earned in developing countries: a policy analysis. The George Washington International Law Review 35 (2): 265-296.

Nilsen, Kristian R.H. 2013. The Concept of Tax Sparing. A General Analysis, and an Analysis and Assessment of the Various Features of Tax Sparing Provisions. Master Thesis, University of Oslo. https://www.jus.uio.no/ior/english/research/projects/global-taxtranparency/publications/the-concept-of-tax-sparing.pdf (accessed 202101-05).

OECD (Organization for Economic Co-operation and Development). 1998. Tax Sparing: A reconsideration. Paris: OECD Publishing.

OECD. 2013. BEPS Action Plan. Paris: OECD Publishing.

OECD. 2015a. Aligning Transfer Pricing Outcomes with Value Creation. Action 3 - 2015 Final Report. Paris: OECD Publishing.

OECD. 2015b. BEPS Action 3: Designing Effective Controlled Foreign Company Rules. Actions 8-10 - 2015 Final Report. Paris: OECD Publishing.

OECD. 2015c. Preventing the Granting of Treaty Benefits in Inappropriate Circumstances. Action 6 - 2015 Final Report. Paris: OECD Publishing. OECD. 2017. Model Tax Convention Commentaries. Paris: OECD Publishing. OECD. 2019a. Programme of Work to Develop a Consensus Solution to the Tax Challenges Arising from the Digitalisation of the Economy. Paris: OECD Publishing.

OECD. 2019b. Global Anti-Base Erosion Proposal (“GloBE”) Pillar Two. Public consultation document. Paris: OECD Publishing.

OECD. 2020. Tax Challenges Arising from Digitalisation - Report on Pillar Two Blueprint. Paris: OECD Publishing. 
Oguttu, Annet W. 2011. The Challenges of Tax Sparing: A Call to Reconsider the Policy in South Africa. Bulletin for International Taxation 65 (1): 1-21.

Oh, Yong S. 1987. A Critique of US Policy on the Tax Sparing Credit, From the Perspective of Less Developed Countries. Korean Journal of Comparative Law 15: 38-66.

Parada, Leopoldo. 2018. Double non-taxation and the use of hybrid entities: an alternative approach in the new era of BEPS. Alphen aan den Rijn: Kluwer Law International.

Peroni, Robert J. 2003. Response to Professor McDaniel's Article. George Washington International Law Review 35: 297-302.

Reese, Paul D. 1987. United States tax treaty policy toward developing countries: the China example. UCLA Law Review 35 (2): 369-398.

Rust, Alexander. 2015. Art. 23 Exemption Method/Credit Method. In E. Reimer and A. Rust (eds.) Klaus Vogel on Double Taxation Conventions. Alphen aan den Rijn: Kluwer Law International.

Santos, J.V. Guedes. 2015. Interpretative Treaty Override, Breach of Confidence and the Gradual Erosion of the Importance of Tax Treaties. Bulletin for International Taxation 69 (1): 17-28.

Sas, Mariela A. and Diplotti, Andrés G. 2005, Tax sparing for developing countries: the Argentinean case, Tax notes international 40 (8): 697-701.

Schoueri, Luis E. 2006. Acordos de bitributação e incentivos fiscais: o papel das cláusulas de tax Sparing \& Matching Credit. Revista Esmafe: Escola de Magistratura Federal da 5a Região 10: 213-222.

Schoueri, Luis E. 2013. Tax sparing: a reconsideration of the reconsideration. In Yariv Brauner and Miranda Stewart (eds.). Tax, Law and Development. Cheltenham: Edward Elgar Publishing, 106-124.

Shannon, Harry A. 1992. Tax incentives and tax sparing. Intertax 20 (2): 8496.

Silva, Natalie M. 2013. As clausulas de tax sparing e matching credit nos acordos de bitributação. Ph.D. diss., Universidade de São Paulo.

Silva, Natalie M. 2012. O Caso Société Natexis Banque Populaire e a Cláusula de Matching Credit do Acordo de Bitributação entre Brasil e França. Direito Tributário Atual 28: 231-248.

Surrey, Stanley S. 1958. The Pakistan Tax Treaty and tax sparing. National Tax Journal 11 (2): 156-167. 
Surrey, Stanley S. 1965. International tax Conventions: how they operate and what they accomplish. Journal of Taxation 23 (6): 364-367.

Thompson Jr. Samuel C. 2003. The case for tax sparing along with expanding and limiting the subpart $\mathrm{F}$ regime. The George Washington International Law Review 35 (2): 303-314.

Tillinghast, David R. 1995. Tax treaty issues. University of Miami Law Review 50 (3): 455-482.

Toaze, Deborah. 2001. Tax sparing: good intentions, unintended results. Canadian Tax Journal 49 (4): 879-924.

UN (United Nations). 2017. Commentaries to the Model Double Taxation Convention. New York: United Nations.

Whittaker, Donald R. 1982. An examination of the O.E.C.D. and U.N. model tax treaties: history, provisions and application to U.S. foreign policy. North Carolina Journal of International Law and Commercial Regulation 8 (1): 369-398.

$\mathrm{Xu}$, Yan. 2017. Foreign tax credits and the complexity of tax law: China as a case study. Australian Tax Review 46 (2): 120-136.

\section{Notes on contributor}

Dr. Aitor Navarro, LL.M. is an Assistant Professor in Tax Law at Carlos III University, Madrid. His main lines of research focus on transfer pricing, corporate taxation, and international taxation matters. His book “Transactional Adjustments in Transfer Pricing” was awarded the 2019 IBFD Frans Vanistendael Award for International Tax Law. He lectures regularly on Spanish tax law as well as European Union and International tax law in several undergraduate and LL.M. programs, and he participates as a speaker in seminars and conferences, mostly at an international level. He is also the deputy director of the LL.M. in Taxation program at Carlos III University. 